\title{
Blended Learning in Integrated Science Learning by a WISE Approach in Homeschooling
}

\author{
Agus Tryanto $^{1^{*}}$, Moch. Sukardjo ${ }^{2}$, Eveline Siregar \\ 1,2,3 Postgraduate Educational Technology, State University of Jakarta, Jakarta, Indonesia
}

\section{A R T I C L E I N F O}

Article history:

Received September 29, 202

Revised September 30, 2021

Accepted October 12, 2021

Available online November 25, 2021

Kata Kunci:

Blended Learning, Pendekatan WISE,

Homeschooling

Keywords:

Blended Learning, WISE Approach,

Homeschooling

DOI:

https://dx.doi.org/10.23887/jet.v5i4.38 365

\begin{abstract}
A B S T R A K
Kurangnya variasi pembelajaran yang dilakukan homeschooling sedangkan homeschooling dituntut untuk lebih kreatif, mandiri dan inovatif. Blended learning akan menjadi opsi pembelajaran yang inovatif dan sesuai karakter homeschooling. Penelitian ini bertujuan untuk mengembangkan blended learning pada mata pelajaran IPA dengan pendekatan WISE di Homeschooling. Penelitian yang bertajuk penelitian pengembangan (R\&D). Metode pengembangan dengan menggunakan perpaduan antara model flipped learning dengan model web-based design dengan pengambilan data menggunakan triangulasi data. Instrumen yang digunakan untuk mengumpulkan data yaitu kuesioner. Produk akan melalui proses evaluasi dari para ahli dan evaluasi kelayakan maupun efektifitas. Review ahli terdiri dari review ahli media dan ahli desain pembelajaran dan review ahli materi dan bahasa. Tahapan kelayakan dilakukan dengan one-to-one test, small group test dan field test. sedangkan untuk uji efektivitas dilakukan sampai evaluasi sumatif dengan perhitungan N-Gain score. Hasil akhir menyatakan blended learning layak dengan rerata 3,5 pada riview ahli dengan dinyatakan sangat baik dan efektif dengan hasil perhitungan rerata $N$-Gain 0,61 pada kategori baik. Maka dengan adanya Blended Learning, pembelajaran yang ada di Homeschooling menjadi kreatif, inovatif, dan mandiri. Implikasi penelitian yaitu penerapan blended learning pada Homeshooling akan meningkatkan suasana belajar yang menyenangkan.
\end{abstract}

\section{A B S T R A C T}

The lack of variety of learning is carried out by Homeschooling, while Homeschooling is required to be more creative, independent, and innovative. Blended learning will be an innovative learning option and according to the character of Homeschooling. This study aims to develop blended learning in science subjects with the WISE approach in Homeschooling. The research is entitled development research $(R \& D)$. The development method uses a flipped learning model with a webbased design model with data collection using data triangulation. The instrument used to collect data is a questionnaire. The product will go through an evaluation process from experts and evaluate its feasibility and effectiveness. Expert reviews consist of reviews of media experts and learning design experts and reviews of material and language experts. The feasibility stage is carried out by one-to-one test, small group test, and field test. In comparison, the effectiveness test is carried out to summative evaluation by calculating the $\mathrm{N}$-Gain score. The final result states that blended learning is feasible with an average of 3.5 on expert reviews, which is very good and effective with the calculation results of the average N-Gain 0.61 in the excellent category. So with Blended Learning, learning in Homeschooling becomes creative, innovative, and independent. The research implication is that the application of blended learning in Homeschooling will increase a pleasant learning atmosphere.

This is an open access article under the CC BY-SA license. Copyright (C) 2021 by Author. Published by Universitas Pendidikan Ganesha.

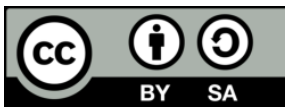

\section{INTRODUCTION}

Education is a place for students to develop various potentials through the learning process (Boyadzhieva, 2016; Hamzah \& Mentari, 2017; Outhwaite et al., 2019). Students actively build their knowledge and teachers try to develop the student competencies. In line with that, a strong pillar is needed for the achievement of good education (Lian et al., 2020; Taimur \& Sattar, 2018). A nation child has the right to obtain education and the government is obliged to build an education system so the learning can be conducted properly. In addition, a great education system can produces graduates who are able to provide better changes for the nation and compete with other countries in various aspects including technology (Barnes et al., 2019; Ran \& Jinglu, 2020; Seibert, 2020). In achieving this eagerness, a good education system is required to create 
competent and quality human resources. The development of the era provides differences and changes. For example, the communication changes from using letter to cellphone for communicating. It shows that there is change in a more advanced direction to be more practical and instant. The use of mobile phone as technology today is part of the development of Information and Communication Technology (ICT) (Balan et al., 2019; Dashtestani, 2013; Malik, 2018). The use of ICT in education is included in learning patterns and interactions. Various learning models that utilize ICT have been developed, such as e-learning, web-based learning, online learning, distance learning, and also Blended Learning (Bervell \& Arkorful, 2020; Bock et al., 2018; Ghavifekr \& Rosdy, 2015). Not only in conventional education, the use of ICT in alternative education also changes, one of which is homeschooling.

Based on the findings from homeschooling, the learning that is widely circulated in homeschooling can be said to be monotonous, in fact it is no different from conventional education. Homeschooling that prioritizes independent learning and freedom in learning will collide with learning activities that are equated with learning models that are usually carried out in formal schools (Neuman, 2020; Purwaningsih \& Fauziah, 2019). Many ways have been done to improve learning in homeschooling, one of which is blended learning. Blended learning that has been used by homeschooling only combines several media and other learning activities, limited knowledge in developing blended becomes a separate obstacle in developing a learning (Abramovitz et al., 2012; Bervell \& Arkorful, 2020). Blended Learning is an effective combination of two components. The components referred to here are face-to-face learning and online learning (Akyol \& Garrison, 2011; Lukitasari et al., 2019). From the statements above, it can be concluded that Blended Learning is a mixed learning between face-to-face and online meetings with various kinds of tools/tools and the use of various strategies so that they become a complementary unit to create an effective learning environment in achieving learning objectives (Lapitan et al., 2021; Widana et al., 2018). Blended Learning allows students to control their learning individually. Blended Learning supports enhancement outreach to learners by connecting a worldwide workforce, working virtually, and continuously (Maarop \& Embi, 2016; Mali \& Lim, 2021). In addition, blended learning resources can be accessed by students anytime and anywhere, and accommodate individuals with visual, audio, and mobility. Thus, the blended learning creates insight for skill development more inclusive (Akhmalia et al., 2018; Yusoff et al., 2017).

One of the in online-based learning approach is the uses the Web-based Inquiry Science Environment (WISE). One approach in online-based learning is to use the Web-based Inquiry Science Environment (WISE). The use of WISE makes it easy for students to learn, develop ideas, observe phenomena and solve problems virtually and online (Linn et al., 2010; Matuk et al., 2019). with WISE can also help researchers who are oriented towards learning science inquiry. Thus, it will help science learning. WISE modelling in science subjects encourages students to learn independently with an online inquiry approach. Home schooling is a school with a focus on independent learning without meeting directly with the teacher. WISE has the ability to interpret graphs and graphs on the concept of motion (Cooper et al., 2020; Hong et al., 2021). Based on field observations, There have been many primary and secondary education, in this case elementary to high school/vocational education levels, that have implemented Blended Learning (Bervell \& Arkorful, 2020; Bock et al., 2018; Sudiarta \& Sandra, 2016). To see the novelty of this research that the application of Blended Learning in homeschooling which has been slightly touched by other researchers is very necessary. Blended Learning is made in its entirety, both online learning and face-to-face learning, where face-to-face learning produces learning strategies that must be carried out in class while online learning will produce web courses (Hrastinski, 2019; Kurniawati et al., 2019; Yigzaw et al., 2019). On the online learning side, the WISE approach is used to support science-based learning, in this case the researcher focuses on Integrated Science lessons. This research is a further development process from the studies mentioned above to determine the extent to which blended learning is applied to alternative school levels by adding new variables to the learning object. blended learning developed specifically for homeschooling, the characteristics and use of a more specific development model for blended learning. Thus, this study has a novelty from previous studies. Based on the background of the problem, the focus of this research is the development of Blended Learning in Integrated Science Subjects with the WISE Approach at Homeschooling Taman Sekar Bandung. The lack of learning development in HTSB and blended learning at homeschooling. So the formulation of the problem is how to develop Blended Learning in Integrated Science Subjects with the WISE Approach at Homeschooling Taman Sekar Bandung.

\section{METHOD}

This type of research is research and development that will produce a learning product from blended learning. The use of the R\&D model will make research a mixture of qualitative and quantitative (Mix Method Design). The models that will be used in the development of Blended Learning are Flipped Learning and Web Based Design models. The two models were chosen because of the combination that will provide detailed stepby-step guidance according to their functions so that they are expected to produce products that are worthy of 
use. The Flipped Learning model is used in developing learning strategies while the web based design model is used because the development steps specifically provide guidance in developing teaching materials using online media. The research location will be conducted at Taman Sekar Homeschooling Bandung. sampling using purposive sampling technique. The target of the study was 8th grade HTSB students with a sample of 20 students. The study time lasts for one semester in 2021. Data collection by collecting combined data in the form of interviews, observations, and tests (data triangulation) The use of the Flipped Learning model is combined with the Web Based Design model because Flipped Learning is in accordance with the HTSB model that implements multiple homeschooling (muhtadi), a combination of learning together with independent learning and the use of Web Based Design models to support the online model of science learning that uses the WISE approach, an approach inquiry science online. The blended learning development model in learning needs to be tested to determine its quality and feasibility. The model trial is part of a series of validations, evaluations and revisions that will be carried out by involving 2 experts in the fields of instructional design and media as well as in the fields of material and language, one-on-one trial on 3 students, limited trial on 9 students and testing the effectiveness by using a field test. In the expert test section using standardized instruments and in the one-to-one test section until the field test is used according to the model developed from jollife.

Table 1. The Grid of Intrument

\begin{tabular}{|c|c|c|}
\hline No & Aspect & INDICATOR \\
\hline 1 & Learning Aspect & $\begin{array}{l}\text { Clarity of the formulation of learning objectives } \\
\text { Completeness of a brief explanation in the introduction } \\
\text { Ability to provide motivation for goals } \\
\text { The suitability of the tasks or exercises provided with the learning objectives } \\
\text { Clarity of conclusions or summaries presented } \\
\text { Evaluation presentation } \\
\text { The suitability of the method used with the learning objectives on the web with } \\
\text { the syllabus } \\
\text { Material lineage }\end{array}$ \\
\hline 2 & Material Aspect & $\begin{array}{l}\text { Relevance of the material to the purpose } \\
\text { Material Depth } \\
\text { the material presented achieves the learning objectives } \\
\text { Clarity of description of the material presented } \\
\text { the completeness of the learning components provided } \\
\text { material sufficiency } \\
\text { Material news } \\
\text { the adequacy of the reference (reference) used }\end{array}$ \\
\hline 3 & Language Aspect & $\begin{array}{l}\text { correct spelling used (EYD) } \\
\text { editorial clarity and ease of understanding } \\
\text { the accuracy of the use of examples, and non-examples, } \\
\text { Use of language style } \\
\text { Language style } \\
\text { Readability (redaction error) }\end{array}$ \\
\hline
\end{tabular}

The types of data that will be obtained in this development are qualitative and quantitative. Qualitative data were obtained from the responses of media, design, material, and student experts about the products produced, while quantitative data were obtained from questionnaires and learning outcomes. The indicators used in this study refer to Jolilffe et.al. Indicators of student learning outcomes refer to the small group and the one on one test evaluation questionnaire Jolliffe et.al. $\mathrm{N}$-gain score on pre-test and post-test to see the effectiveness of blended learning.

\section{RESULT AND DISCUSSION}

\section{Result}

There are two major stages, namely semester level and lesson level. The semester level consists of the analysis stage and the design stage which will produce a curriculum prototype that will be processed at the next stage. The lesson level stage consists of two major stages, the online stage and the face-to-face stage. Online is developed by gathering information, developing materials, and producing materials. Face-to-face was developed with face-to-face analysis, face-to-face development, and evaluation. The findings of the initial observations at HTSB with the open interview method were the limited use of the online learning in the form of email and video 
calls. HTSB has never applied blended learning to science subjects with the WISE approach all this time. Therefore, the blended learning is expected to foster learning motivation and increase students' competence. Blended Learning can assist students overcome learning problems, overcome time constraints to conduct learning activities, improve student learning outcomes while encouraging independence, and motivate students in integrated science subjects. The designs that will be used in the development of Blended Learning are Flipped Learning and Web Based Design models. Both models were chosen because they provide clear steps related to their function. It is expected to produce useful products. The Flipped Learning model is used in developing learning strategies while the web based design model is used to provide guidance in developing teaching materials using online media. This research uses Flipped Learning model and Web Based Design model. the results of the development of the two models into a combination that will be used in this study.

There are two stages in designing the semester level. The analysis stage is the initial stage of the development. First, the researcher analyzed the objectives of integrated science learning with the WISE approach in class VIII. Furthermore, the content and topics in integrated science learning with the WISE approach in class VIII which were conducted for one semester were analyzed. Then, the researcher analyzed the students' needs by observing their previous knowledge, and prerequisite learning before conducting integrated science with the WISE approach in class VIII. Then, the researcher analyzed the facilities and infrastructure that support blended learning in integrated science with the WISE approach in class VIII. These analyzes are used to manage the allocation time of online and face-to-face learning. The design stages are divided into five parts, namely: outline design of learning content; learning strategy design; face-to-face activity design; online activity design; and learning evaluation design. The first stage is the activity of designing needs to develop online learning. At this stage, the researcher prepares web activity information documents, develops student competency profiles and sub-profiles, develops learning objectives, and determines assessment guidelines. This result is produces learning objectives in science subjects in class VIII. Core Competencies (KI) and Basic Competencies (KD) in class VIII. Referring to the established KI and KD, there are five topics that will become teaching materials in blended learning.

Table 2. Five Topics That Will Become Teaching Materials

\begin{tabular}{lc}
\hline No & Topic \\
\hline 1 & Substance Pressure and Its Application in Daily Life \\
2 & Human Respiratory System \\
3 & Human Excretory System \\
4 & Vibrations, Waves and Sounds in Daily Life \\
5 & Light and Optical Instruments \\
\hline
\end{tabular}

At this stage a strategy is determined in the form of determining learning patterns to carry out online and face-to-face classes based on the previous step. Existing topics are determined by strategies for their implementation, in the blended learning section, independent learning is used with the WISE approach, while for face-to-face learning collaborative learning is used. Learning resources are selected and determined based on the material developed. The development of the screen display is the initial design for the development of a learning website. The website was developed by PHP-based software with a moodle display adapted to the characteristics of students at HTSB. Furthermore, constructing a flowchart or navigation flow related to Integrated Science Learning with the WISE approach as follows. The next step is to enter all the learning materials into the web. Face-to-face analysis deals with developed online content. Online material is a requirement for face-to-face learning. Furthermore, researchers designed face-to-face activities by observing the procedures, time allocation, and proportions of activities. At this stage, based on the analysis that has been done previously, on material with learning activities carried out face-to-face, students are required to study the material independently online. This activity is carried out to form students' initial understanding before entering the classroom. Furthermore, the students will answer the questions that have been prepared as a measure of how far students understand and what needs to be learned while in class. In face-to-face classes, subjects provide lectures, questions and answers, and practice on the material, especially understanding/concepts that need to be further strengthened based on the results of the ability test before entering the class. There are changes in classroom activities due to restrictions on school activities as a result of the COVID-19 pandemic, so face-to-face activities are directly replaced with Zoom meeting activities. Researcher develops the syllabus into a Lesson Plan (RPP) for offline activities. Researchers also design formative and summative evaluations in the Student Worksheet (LKS). The last stage is evaluation. The evaluation uses a standardized evaluation developed by Eveline for network-based media. The material is tested by material experts of the Integrated Science learning in class VIII which includes aspects of learning, material, and language. The results of the material expert test showed that the average value of the learning aspect was 3.4, the material aspect was 3.4 and the language aspect was 3.5 with a total average of 3.4. 
This result was interpreted greatly, which means it is feasible to develop the next stage. Experts also suggested that the product can be maximized by.

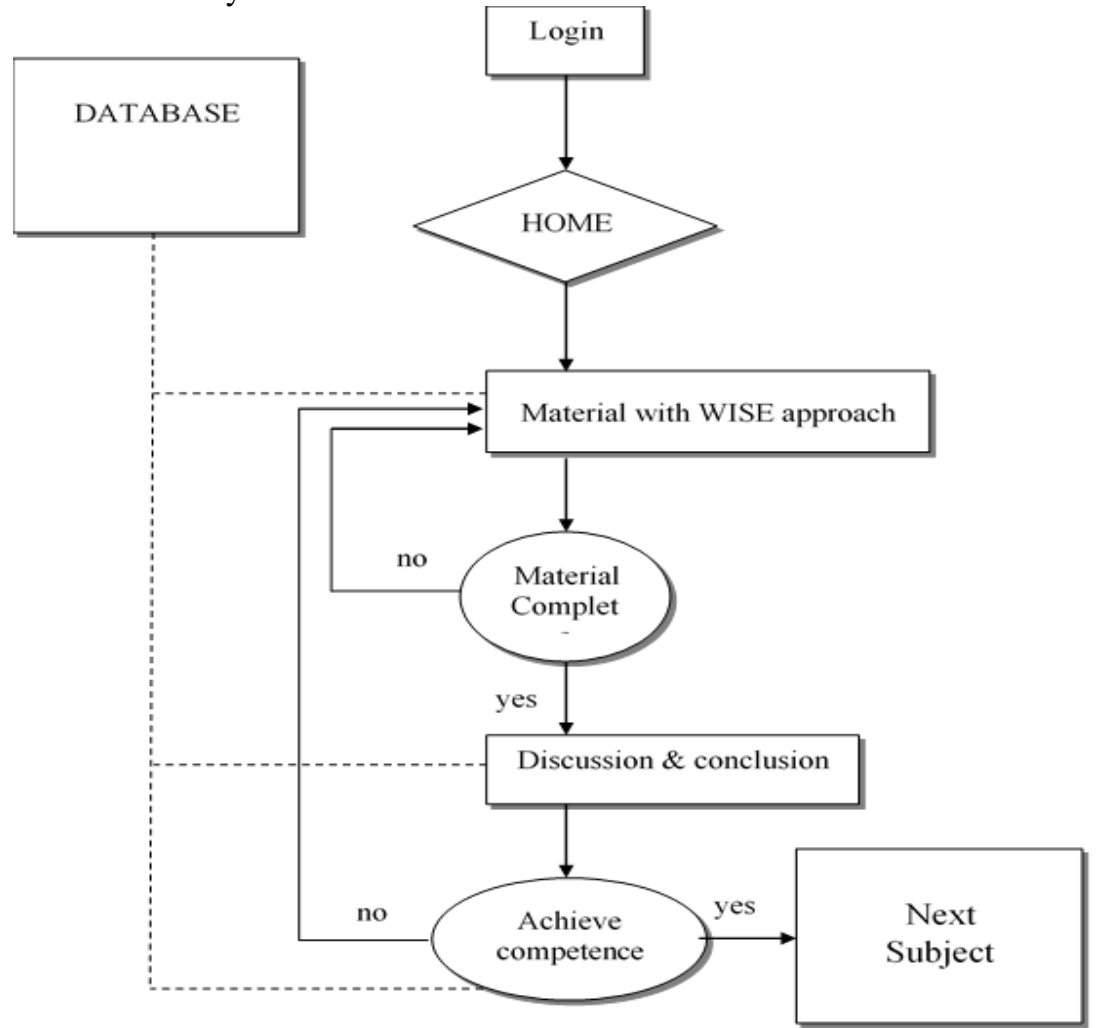

Figure 1. Online Learning Flowcharts

Table 3. Suggetion and Action of Material Test

\begin{tabular}{|c|c|c|}
\hline No & Suggestion & Action \\
\hline 1. & $\begin{array}{l}\text { The material is presented greatly, but the } \\
\text { opening and closing of each material needs to } \\
\text { be clarified. }\end{array}$ & Corrected the opening and closing of each chapter. \\
\hline 2. & $\begin{array}{l}\text { An evaluation per chapter of the material is } \\
\text { held so the students can write and multiple- } \\
\text { choice evaluations for all chapters are } \\
\text { reproduced. }\end{array}$ & $\begin{array}{l}\text { Inserting practice tests in each chapter and improve } \\
\text { evaluation tests at the end of the lesson. }\end{array}$ \\
\hline
\end{tabular}

Instructional design and media experts will observe the feasibility of developing blended learning before tested at the next stage and before giving to students. The results of the instructional and media design expert test that the learning aspect was 3.4, the material aspect was 3.4, and the language aspect was 3.5 which resulted in a total average of 3.4. This result is interpreted greatly which means it is feasible to be developed for the next stage. This stage involved 3 students HTSB with various criteria and learning abilities. Students are given the same instrument after using blended learning. The graph showed that the three students determined that the product developed was feasible and great for learning. It is in related to the interpretation by Sudjana. At this stage, the product was tested on nine students who had participated in Integrated Science learning with the WISE approach. Students filled out the questionnaire. Based on the results, the data acquisition of 3.5 is declared "very good" with some corrections and suggestions from correspondents. They present that the material was good. Then the product is declared eligible with a small group test. Thus the product can be used for this research. Student performance was reviewed using pre-test and post-test analysis. it is used to test the effectiveness of online material development products on the learning process. The results of the pre-test and post-test analysis are shown in the N-Gain Score. The results of the pre-test and post-test data analysis showed that the increase in learning outcomes of 2 students was in the high category, 18 students in the medium category, and there were no students in the low category in using it. So it can be concluded that the developed blended learning can improve the learning outcomes of the trainees effectively. 


\section{Discussion}

In the era of technology that is advancing very rapidly, it is necessary to change the pattern of education in both formal and non-formal environments (Gil-Flores et al., 2017; Pöntinen \& Räty-Záborszky, 2020). Homeschooling is an alternative education for students to be able to receive education in a home-study format (Herfinaly \& Aryani, 2013; Purwaningsih \& Fauziah, 2019). Homeschooling is the target of research due to the lack of development carried out in the education. A new trend in the world of education, especially in the $21 \mathrm{st}$ century, by combining online and face-to-face which was later refined into blended learning. Blended learning studies have been believed by many to significantly improve student learning goals (Shamsuddin \& Kaur, 2020; Tobing \& Pranowo, 2020). Thus, the combination of homeschooling using blended learning becomes the latest research as well as providing options for homeschooling towards educational innovation. The feasibility of blended learning must be known before being used. The feasibility of the material is seen from the ability of the material to meet the feasibility assessment standards from the National Education Standards Agency (BNSP) which consists of content feasibility, language feasibility, presentation feasibility, and graphic feasibility (Siregar et al., 2018).

The Blended Learning model as a distance learning method can be used to adapt learning needs, such as being able to learn anywhere and anytime (Hogan \& Devi, 2019; Müller et al., 2021; Wu et al., 2019). With this learning material, students can learn in their own way and at their own pace according to their abilities (Choi et al., 2021; Li et al., 2018). This Web Course is implemented and combined with face-to-face so that it is able to improve the independent learning experience for students, students can achieve their learning outcomes according to their abilities and pace of learning (Bilik et al., 2020; Muhametjanova \& Akmatbekova, 2019; Spector, 2016). The development of Blended Learning has implications for teachers as tutors and students where students get appropriate learning resources that can be used anytime, anywhere, as well as ease of learning. On the other hand, students can adjust their learning abilities independently without being disturbed by other students and students can easily repeat learning according to their needs (Khalil, 2018; Khamparia \& Pandey, 2017). There is a significant difference in the learning process between homeschooling and conventional education, so that there is a gap between students and one another that can hinder the overall learning process. Reconsidering the subject of learning or students who will use Blended Learning, a different strategy and application is needed if it is carried out in conventional schools or used in alternative schools. The recommendations obtained from the research results are the need for further development by applying blended learning in other subjects and in other semesters. Of course, supported by the ability to develop blended learning itself, then in the future teachers can develop their own subjects.

\section{CONCLUSION}

The result of the research is blended learning of Integrated Science subject material with the WISE approach at Homeschooling Tamansekar Bandung. The development of blended learning uses Lee's development model combined with Jolliffe. Based on media expert tests, instructional designs, and product materials, this product is declared feasible. The effectiveness test of this product shows that student learning achievement exceeds the KKM with satisfactory criteria. The combination of Homeschooling with Blended Learning is the latest research and provides homeschooling options for educational innovation.

\section{REFERENCES}

Abramovitz, B., Berezina, M., Berman, A., \& Shvartsman, L. (2012). A Blended Learning Approach in Mathematics. Teaching Mathematics Online: Emergent Technologies and Methodologies, 21. https://doi.org/10.4018/978-1-60960-875-0.ch002.

Akhmalia, N. L., Suana, W., \& Maharta, N. (2018). Efektivitas Blended Learning Berbasis LMS dengan Model Pembelajaran Inkuiri pada Materi Fluida Statis terhadap Penguasaan Konsep Siswa. JIPFRI (Jurnal Inovasi Pendidikan Fisika Dan Riset Ilmiah), 2(2), 56-64. https://doi.org/10.30599/jipfri.v2i2.299.

Akyol, Z., \& Garrison, D. R. (2011). Understanding cognitive presence in an online and blended community of inquiry: Assessing outcomes and processes for deep approaches to learning. British Journal of Educational Technology, 42(2), 233-250. https://doi.org/10.1111/j.1467-8535.2009.01029.x.

Balan, S., Katenga, J. E., \& Simon, A. (2019). "Reading Habits and their Influence on Academic Achievement among Students at Asia Pacific International University, Thailand.” Abstract Proceedings International Scholars Conference, 7(1), 1469-1495. https://doi.org/10.35974/isc.v7i1.928.

Barnes, S. J., Pressey, A. D., \& Scornavacca, E. (2019). Mobile ubiquity: Understanding the relationship between cognitive absorption, smartphone addiction and social network services. In Computers in Human Behavior (Vol. 90). Elsevier B.V. https://doi.org/10.1016/j.chb.2018.09.013.

Bervell, B., \& Arkorful, V. (2020). LMS-enabled blended learning utilization in distance tertiary education: 
establishing the relationships among facilitating conditions, voluntariness of use and use behaviour. International Journal of Educational Technology in Higher Education, 17(1), 6. https://doi.org/10.1186/s41239-020-0183-9.

Bilik, Ö., Kankaya, E. A., \& Deveci, Z. (2020). Effects of web-based concept mapping education on students' concept mapping and critical thinking skills: A double blind, randomized, controlled study. Nurse Education Today, 86, 104312. https://doi.org/10.1016/j.nedt.2019.104312.

Bock, A., Modabber, A., Kniha, K., Lemos, M., Rafai, N., \& Hölzle, F. (2018). Blended learning modules for lectures on oral and maxillofacial surgery. British Journal of Oral and Maxillofacial Surgery, 56(10), 956-961. https://doi.org/10.1016/j.bjoms.2018.10.281.

Boyadzhieva, E. (2016). Learner-centered Teaching and Learner Autonomy. Procedia - Social and Behavioral Sciences, 232, 35-40. https://doi.org/10.1016/j.sbspro.2016.10.008.

Choi, J. J., Robb, C. A., Mifli, M., \& Zainuddin, Z. (2021). University students' perception to online class delivery methods during the COVID-19 pandemic: A focus on hospitality education in Korea and Malaysia. Journal of Hospitality, Leisure, Sport and Tourism Education, 29(August), 100336. https://doi.org/10.1016/j.jhlste.2021.100336.

Cooper, V. A., Forino, G., Kanjanabootra, S., \& Meding, J. von. (2020). Leveraging the community of inquiry framework to support web-based simulations in disaster studies. The Internet and Higher Education, 47. https://doi.org/10.1016/j.iheduc.2020.100757.

Dashtestani, R. (2013). Implementing mobile-assisted language learning (MALL) in an EFL context: Iranian EFL teachers' perspectives on challenges and affordances. The JALT CALL Journal, 9(2), 149-168. https://doi.org/10.29140/jaltcall.v9n2.153.

Ghavifekr, S., \& Rosdy, W. A. W. (2015). Teaching and learning with technology: Effectiveness of ICT integration in schools. International Journal of Research in Education and Science, 1(2). https://ijres.net/index.php/ijres/article/view/79.

Gil-Flores, J., Rodríguez-Santero, J., \& Torres-Gordillo, J. J. (2017). Factors that explain the use of ICT in secondary-education classrooms: The role of teacher characteristics and school infrastructure. Computers in Human Behavior, 68, 441-449. https://doi.org/10.1016/j.chb.2016.11.057.

Hamzah, I., \& Mentari, S. (2017). Development of Accounting E-Module to Support the Scientific Approach of Students Grade X Vocational High School. Journal of Accounting and Business Education, 1(1), 78. https://doi.org/10.26675/jabe.v1i1.9751.

Herfinaly, R., \& Aryani, L. (2013). Interaksi Sosial Remaja Yang Bersekolah di Homeschooling Dengan Menggunakan Metode Distance Learning. Jurnal Psikologi, 9(1). https://doi.org/10.24014/jp.v9i1.147.

Hogan, R., \& Devi, M. (2019). A synchronous pedagogy to improve online student success. International Journal of Online Pedagogy and Course Design, 9(3), 61-77. https://doi.org/10.4018/IJOPCD.2019070105.

Hong, J.-C., Hsiao, H.-S., Chen, P.-H., Lu, C.-C., \& Tai, K.-H. (2021). Critical attitude and ability associated with students' self-confidence and attitude toward "predict-observe-explain" online science inquiry learning. Computers \& Education, 166. https://doi.org/10.1016/j.compedu.2021.104172.

Hrastinski, S. (2019). What Do We Mean by Blended Learning? TechTrends. https://doi.org/10.1007/s11528019-00375-5.

Khalil, Z. M. (2018). EFL Students' Perceptions towards Using Google Docs and Google Classroom as Online Collaborative Tools in Learning Grammar. Applied Linguistics Research Journal, 2(2), 33-48. https://doi.org/10.14744/alrj.2018.47955.

Khamparia, A., \& Pandey, B. (2017). Impact of interactive multimedia in E-learning technologies: Role of multimedia in E-learning. Enhancing Academic Research With Knowledge Management Principles, April, 199-227. https://doi.org/10.4018/978-1-5225-2489-2.ch007.

Kurniawati, M., Santanapurba, H., \& Kusumawati, E. (2019). Penerapan Blended Learning Menggunakan Model Flipped Classroom Berbantuan Google Classroom Dalam Pembelajaran Matematika Smp. EDU-MAT: Jurnal Pendidikan Matematika, 7(1), 8-19. https://doi.org/10.20527/edumat.v7i1.6827.

Lapitan, L. D., Tiangco, C. E., Sumalinog, D. A. G., Sabarillo, N. S., \& Diaz, J. M. (2021). An effective blended online teaching and learning strategy during the COVID-19 pandemic. Education for Chemical Engineers, 35(May 2020), 116-131. https://doi.org/10.1016/j.ece.2021.01.012.

Li, J., Zhang, X., \& Hu, Z. (2018). The design and application of flip classroom teaching based on computer technology. International Journal of Emerging Technologies in Learning, 13(10), 95-107. https://doi.org/10.3991/ijet.v13i10.9453.

Lian, B., Kristiawan, M., Ammelia, D., Primasari, G., Anggung, M., \& Prasetyo, M. (2020). Teachers' Model in Building Students' Character. Journal of Critical Reviews, 7(14), 927-932. https://doi.org/10.31838/jcr.07.14.165.

Linn, M. C., Slotta, J. D., Terashima, H., Stone, E., \& Madhok, K. (2010). Designing Science Instruction using 
the Web-based. Asia-Pacific Forum on Science Learning and Teaching, 11(2). https://www.eduhk.hk/apfslt/download/v11_issue2_files/foreword.pdf.

Lukitasari, Purnamasari, Utami, \& Sukri. (2019). Blended-Problem-Based Learning: How its impact on students' critical thingking skills? Jurnal Pendidikan Biologi Indonesia, 5(3), 425-434. https://doi.org/10.22219/jpbi.v5i3.10048.

Maarop, A. H., \& Embi, M. A. (2016). Implementation of Blended Learning in Higher Learning Institutions: A Review of Literature. ResearchGate, 9(3), 41. https://doi.org/10.5539/ies.v9n3p4.

Mali, D., \& Lim, H. (2021). How do students perceive face-to-face/blended learning as a result of the Covid-19 pandemic? International Journal of Management Education, 19(3), 100552. https://doi.org/10.1016/j.ijme.2021.100552.

Malik, R. S. (2018). Educational Challenges in 21st Century and Sutainable Development. Journal of Sustainable Development Education and Research, 2(1), 9-20. https://doi.org/10.17509/jsder.v2i1.12266.

Matuk, C., Wanjing Anya, M., Sharma, G., \& Linn, M. C. (2019). The lifespan and impact of students' ideas shared during classroom science inquiry. Computer-Supported Collaborative Learning Conference, 1. https://escholarship.org/uc/item/41n1w9d4.

Muhametjanova, G., \& Akmatbekova, A. (2019). The web-based learning environment in general physics course in a public university in Kyrgyzstan. Eurasia Journal of Mathematics, Science and Technology Education, 15(3). https://doi.org/10.29333/ejmste/100409.

Müller, A. M., Goh, C., Lim, L. Z., \& Gao, X. (2021). COVID-19 Emergency eLearning and Beyond: Experiences and Perspectives of University Educators. Education Sciences, 11(1), 19. https://doi.org/10.3390/educsci11010019.

Neuman, A. (2020). The meaning of learning: homeschooled compared with schooled children. Educational Studies, 46(6). https://doi.org/10.1080/03055698.2019.1668258.

Outhwaite, L. A., Faulder, M., Gulliford, A., \& Pitchford, N. J. (2019). Raising early achievement in math with interactive apps: A randomized control trial. Journal of Educational Psychology, 111(2), 284-298. https://doi.org/10.1037/edu0000286.

Pöntinen, S., \& Räty-Záborszky, S. (2020). Pedagogical aspects to support students' evolving digital competence at school. European Early Childhood Education Research Journal, 28(2), 182-196. https://doi.org/10.1080/1350293X.2020.1735736.

Purwaningsih, N., \& Fauziah, P. Y. (2019). Homeschooling As an Alternative Education in Indonesia: Case Study on Homeschoolers with Mothers' Professional Difference. KnE Social Sciences, 1(5). https://doi.org/10.18502/kss.v3i17.4617.

Ran, W., \& Jinglu, L. (2020). The Design and Development of Digital Books for E-learning. 2020 4th International Conference on Artificial Intelligence and Virtual Reality, 51-55. https://doi.org/10.1145/3439133.3439140.

Seibert, S. A. (2020). Problem-based learning: A strategy to foster generation Z's critical thinking and perseverance. Teaching and Learning in Nursing, 000, 2-5. https://doi.org/10.1016/j.teln.2020.09.002.

Shamsuddin, N., \& Kaur, J. (2020). Students' learning style and its effect on blended learning, does it matter? International. Journal of Evaluation and Research in Education, 9(1). https://doi.org/10.11591/ijere.v9i1.20422.

Siregar, A. D., Yusuf, M., \& Silaban, R. (2018). Analysis of Feasibility Teaching Material on Molecular Shape Topic Based on Criteria Board of National Education Standards in Indonesia. Atlantis Press, 200. https://doi.org/10.2991/aisteel-18.2018.11.

Spector, J. M. (2016). Educational Technology Program and Project Evaluation. In Educational Technology Program and Project Evaluation, 1(1). https://doi.org/10.4324/9781315724140.

Sudiarta, I. G. P., \& Sandra, I. (2016). Pengaruh Model Blended Learning berbantuan Video Animasi Terhadap Kemampuan Pemecahan Masalah dan Pemahaman Konsep Siswa. Jurnal Pendidikan Dan Pengajaran, 49(2). https://doi.org/10.23887/jppundiksha.v49i2.9009.

Taimur, S., \& Sattar, H. (2018). Education for Sustainable Development and Critical Thinking Competency. Springer Nature Switzerland AG, September, 1-11. https://doi.org/10.1007/978-3-319-69902-8_64-1.

Tobing, R. L., \& Pranowo. (2020). Blended learning in French intermediate grammar learning: Is it effective? Cakrawala Pendidikan, 39(3). https://doi.org/10.21831/cp.v39i3.32035.

Widana, I. N. S., Sumaryani, N. P., Ayuning, N. L. W., \& Pradnyawati. (2018). Memicu Kemampuan Berpikir Kritis dan Hasil Belajar Biologi melalui Model Blended Learning Berbantuan Komik Digital. Emasains, 7(1), 38-48. https://doi.org/10.5281/zenodo.1407735.

Wu, W. H., Kao, H. Y., Wu, S. H., \& Wei, C. W. (2019). Development and evaluation of affective domain using student's feedback in entrepreneurial Massive Open Online Courses. Frontiers in Psychology, 10(MAY). https://doi.org/10.3389/fpsyg.2019.01109. 
Yigzaw, M., Tebekaw, Y., Kim, Y.-M., Kols, A., \& Ayalew, F. (2019). Comparing the effectiveness of a blended learning approach with a conventional learning approach for basic emergency obstetric and newborn care training in Ethiopia. Midwifery, 78. https://doi.org/10.1016/j.midw.2019.07.014.

Yusoff, S., Yusoff, R., \& Noh, N. . (2017). Blended Learning Approach for Less Proficient Students. SAGE Open, 7(3), 1-8. https://doi.org/10.1177\%2F2158244017723051. 